\title{
Review
}

\section{Effects of plants and plant products on the testis}

\author{
Shereen Cynthia D’Cruz, Selvaraju Vaithinathan, Rajamanickam Jubendradass, Premendu Prakash Mathur \\ Department of Biochemistry \& Molecular Biology, School of Life Sciences, Pondicherry University, Pondicherry 605014, India
}

\begin{abstract}
For centuries, plants and plant-based products have been used as a valuable and safe natural source of medicines for treating various ailments. The therapeutic potential of most of these plants could be ascribed to their anticancer, antidiabetic, hepatoprotective, cardioprotective, antispasmodic, analgesic and various other pharmacological properties. However, several commonly used plants have been reported to adversely affect male reproductive functions in wildlife and humans. The effects observed with most of the plant and plant-based products have been attributed to the antispermatogenic and/or antisteroidogenic properties of one or more active ingredients. This review discusses the detrimental effects of some of the commonly used plants on various target cells in the testis. A deeper insight into the molecular mechanisms of action of these natural compounds could pave the way for developing therapeutic strategies against their toxicity.
\end{abstract}

Asian Journal of Andrology (2010) 12: 468-479. doi: 10.1038/aja.2010.43; published online 21 June 2010.

Keywords: male reproduction, natural products, plants, spermatogenesis, steroidogenesis, testis

\section{Introduction}

Male reproduction is a multifaceted process that involves the testes, epididymis, accessory sex glands and associated hormones. Testes perform two highly organized and intricate events, called spermatogenesis and steroidogenesis, which are vital for the perpetuation of life. Spermatogenesis, a highly dynamic and synchronized process, takes place within the seminiferous tubules of the testis with the support of somatic Sertoli cells, leading to the formation of mature spermatozoa from undifferentiated stem cells [1]. The interstitial

Correspondence to: Dr Premendu Prakash Mathur, Department of Biochemistry \& Molecular Biology, School of Life Sciences, Pondicherry University, Pondicherry 605014, India.

Fax: +91-413-265-5211

E-mail: ppmathur@gmail.com; ppmathur.bic@pondiuni.edu.in

Received: 1 April 2010

Accepted: 13 May 2010
Revised: 29 April 2010

Published online: 21 June 2010 compartment, which comprises Leydig cells, are the site of steroidogenesis [2]. Subsequent to the process of spermatogenesis, spermatozoa transits from the testis to the ejaculatory ducts, undergoing a sequence of modifications that results in the accomplishment of its ability to move, capacitate and to interact with zona pellucida of the female ovum [3]. This complex process is strictly regulated by the hypothalamopituitary-testicular axis, which involves the pituitary gonadotropins, luteinizing hormone (LH) and folliclestimulating hormone (FSH). Apart from LH, FSH and androgens, various growth factors, hormones and estrogens are involved in regulating the testicular functions.

The testis is well equipped with powerful intrinsic defense systems that protect the spermatozoa during its spermatogenic/post-spermatogenic journey and from the injuries caused by other intrinsic or extrinsic factors. Nevertheless, the testis is one of the organs that are very vulnerable to assault, which is reflected by the adverse 
trend in male reproductive health during the past several years. The male reproductive system is extremely sensitive to various environmental factors such as life style, drugs, radiation, pollution and toxicants, the result of which could be congenital abnormalities in infants and functional alterations in adults [4]. Several natural and synthetic products are reported to target the testis at the hormonal level or spermatogenesis or both. In this review, we discuss on some of the commonly used plant products that could hamper the functionality of the testis, thereby leading to infertility.

\section{Plants that impair testicular functions}

Plants, since ancient times, have been used globally across varied cultures throughout the known civilizations as a valuable and safe natural source of medicines and as agents of therapeutic, industrial and environmental utilities. From the inception of civilization, humans have relied on plants that could meet their basic necessities such as food, shelter, clothing, fuel and health. Of all the uses ascribed to the plants, their curative abilities played an inevitable part in the lives of primitive societies, as plants comprised their sole source for healing ailments. The sacred knowledge about the healing powers of plants was initially passed down orally through generations, and as civilizations grew written records were prepared for the benefit of the population [5]. The Indian and Chinese systems of traditional medicine are well established, with written records dating back to thousand of years [6]. A wide majority of herbal plants possess pharmacological principles, which has rendered them useful as curatives for numerous ailments. According to the World Health Organization (WHO) reports, $70 \%-80 \%$ of the world population confide in traditional medicine for primary healthcare [7].

Plants have a long folklore of use in aiding fertility. The Indian sacred text, Rig Veda, describes a 'holy brew' called soma, the intake of which is believed to bestow upon humans infinite powers, including aphrodisiacal qualities [8]. The medical historians have recorded plants that could be used as contraceptives, emmenagogues and abortifacients [5]. The safety of many of the herbal drugs is only relative, but the population feels more assured because of their long and widespread usage and their familiarity with plants. Plants are known to heal as well as hurt. Several plants are reported to enhance reproductive processes but, on the other hand, to also hinder testicular functions. The effects of plants on testicular functions could be rightly compared with those of a double-edged sword. This review is confined to the toxicological attributes of some of the commonly used plants to the functions of testis.

\section{Plants that affect spermatogenesis}

Spermatogenesis is a complex process by which an interdependent population of undifferentiated germ cells undergoes multiplication and maturation to form functional haploid spermatozoa. Spermatogenesis consists of three phases: (a) the spermatogonial phase; (b) the spermatocyte phase; and (c) the spermatid phase. During the spermatogonial phase, the diploid spermatogonium undergoes mitosis to form stem cells and primary spermatocytes. This is followed by the spermatocyte phase, in which the primary spermatocytes undergo two rounds of meiosis to form haploid spermatids. The final phase, also called spermiogenesis, involves the differentiation of immature spermatids into mature spermatozoa. Spermiogenesis comprises polarization of the spermatid, formation of acrosomal cap and flagellum, cytoplasmic remodeling and elongation of the nucleus. Endocrine regulation by testosterone and the architecture of the Sertoli cells and seminiferous tubules also forms an important decisive factor in spermatogenesis [9].

Several plants and plant products are reported to impede various stages of testicular spermatogenesis in many different animal species such as dogs, rats, humans and monkeys [10-12] (Figure 1). Cannabinoids, one of the oldest narcotic drugs of plant origin, are known to impair human health since olden times [13]. Intraperitoneal injection of mice with low doses of Cannabis extracts (40 mg, $60 \mathrm{mg}$ and $80 \mathrm{mg}$ ) was reported to induce increased lipid peroxidation in the testis, along with concomitant decrease in the levels of antioxidant enzymes such as superoxide dismutase, catalase and glutathione peroxidase. Damage to the basement membrane, shrinkage of the seminiferous tubules, scanty cytoplasm and shrunken nuclei in the germinal epithelium, and complete arrest of spermatogenesis were also reported. The effects were seen to be reversed on withdrawal of the drug for 45 days, and it was speculated that the endogenous antioxidant system along with the FSH/LH feedback loop was responsible for the observed protective effects on withdrawal [14]. A pharmacokinetic study on the plasma, brain and testis of rats was conducted, which measured the concentration of tetrahydrocannabinol in these tissues following exposure to $\mathrm{C}^{14} \Delta-8$-labeled tetrahydrocannabinol. Impairment of spermatogenesis 


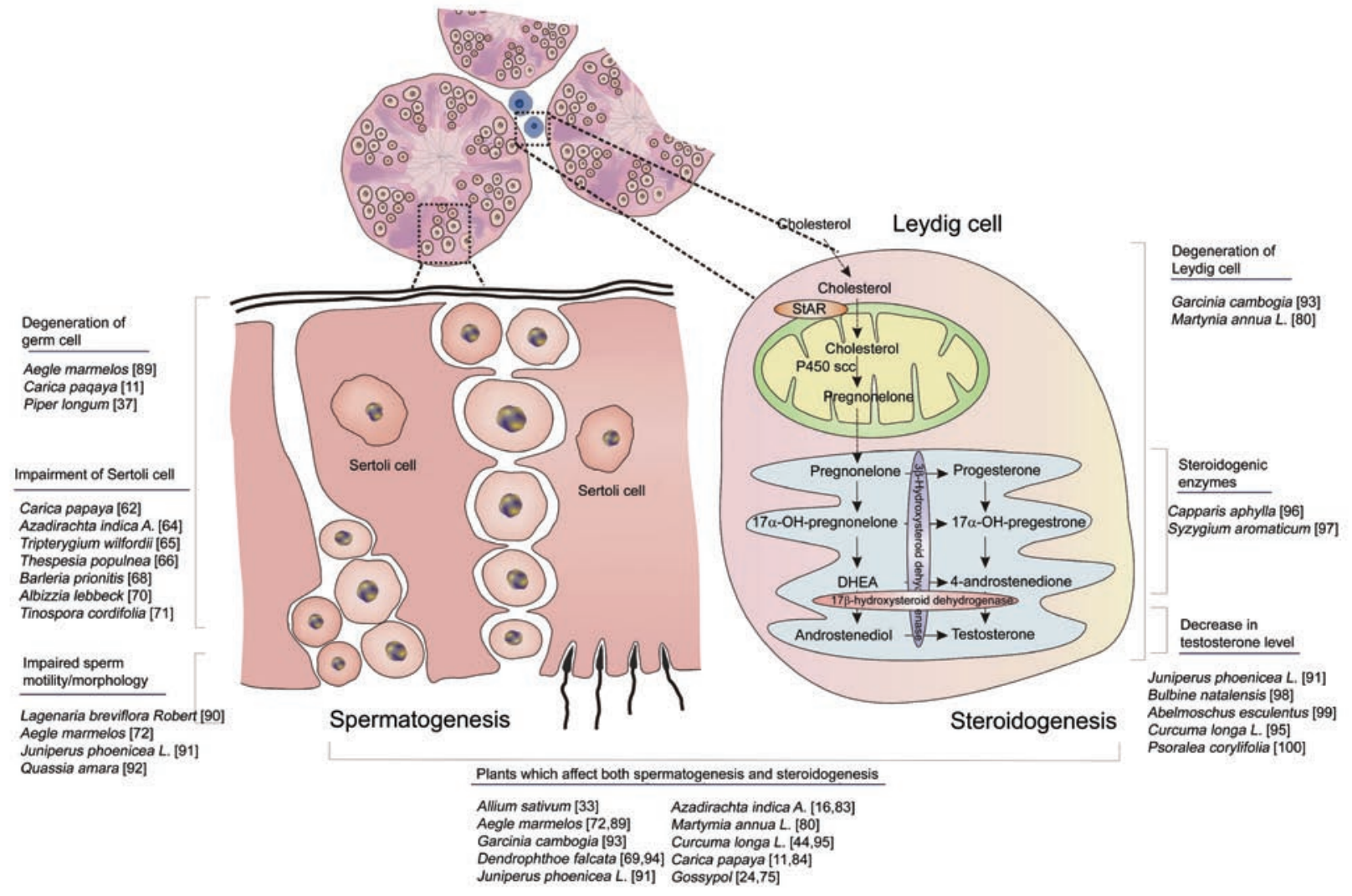

Figure 1. Target sites of plant toxicity in testis.

before the stage of meiosis and premature apoptosis along with structural and functional anomalies of sperm cells were reported. It was hypothesized that tetrahydrocannabinol, a lipid molecular signal, desynchronizes the membrane signaling and induces a death signal in the lipid bilayer, leading to early apoptosis in sperm cells [15].

Neem (Azadirachta indica) has long been documented to have antifertility effects $[16,17]$. The aqueous leaf extract of neem when administered to male mice at a dose of $200 \mathrm{mg} \mathrm{kg}^{-1}$ for 28 days damaged the seminiferous tubules, resulting in the slackening of germinal epithelium, marginal condensation of chromatin in round spermatids, degeneration of germ cells and the derangement of germ cell types from their orderly arrangement in spermatogenesis. The effects were reported to revert back to normalcy after 42 days of withdrawal of the treatment [18]. On the contrary, azadiractin, an active ingredient of neem, given at doses of $5 \mathrm{mg}, 10 \mathrm{mg}$ and $50 \mathrm{mg}$ per $\mathrm{kg}$ body weight (b.w.) did not show any evidence of reproductive toxicity in parent rats or litters $(\mathrm{F}[1 \mathrm{~B}]$ and $\mathrm{F}[2 \mathrm{~B}])$ over two generations, implicating the safe use of the compound as a biopesticide [19]. Although several studies claim the potential use of neem as a contraceptive, neem oil is reported to induce other toxic effects, such as severe metabolic acidosis [20,21], encephalopathy [22], ventricular fibrillation [23] and nervous abnormality.

Gossypol, a polyphenolic compound present in the stem, seeds and roots of Gossypium species, is known to exert unique and selective effects upon reproduction in various species such as rats, mice, hamsters, rabbits, monkeys and human beings [24]. The contraceptive effect of gossypol was first discovered in China. During the times of drought in China, the cotton cake that was left over after the extraction of the oil from the fiber of the plant was consumed by animals and humans. Shortly after, the contraceptive action of cotton cake was identified and immense quantities of gossypol were extracted from the cotton plant. This discovery led to large-scale testing of gossypol as a male contraceptive in China during the 1970s [25]. Gossypol is reported to invoke antifertility effects in rats at $30 \mathrm{mg}$ per $\mathrm{kg}$ b.w., whereas a much lesser dose, $0.3 \mathrm{mg}$ per $\mathrm{kg}$ b.w., could incite infertility in humans, making the compound very efficient in humans than in rats [12]. Later, it was 
found to reduce blood potassium (hypokalemia) [26], and the sterilization effect was found to be irreversible, although a few studies claim the effect to be reversible. Supplementation with potassium salts has been reported to bring normalcy in the gossypol-treated animals. The WHO investigators claim that gossypol has a slow recovery pattern and irreversible effect, and the safety and efficacy of gossypol as a contraceptive continue to be controversial [27].

Carica papaya is recognized from ancient times for its medicinal properties and the contraceptive characteristics of papaya seed extracts have been reported in the 1970s [28, 29]. Degeneration of germ cells and germinal epithelium, reduction in the number of Leydig cells and presence of vacuoles in the seminiferous tubules were observed when crude ripe seeds of papaya were administered orally to male Wistar rats at a dose of $100 \mathrm{mg}$ per kg b.w. [11]. The crude chloroform extract of papaya seeds at a dose of 5 mg per animal per day for 40-60 days reduced the fertility potential to $0 \%$, with the suppression of cauda epididymal sperm motility [30]. Administration of the chloroform extract of papaya to male rabbits for 150 days caused a decline in sperm concentration with oligospermia on the 75 th day and azoospermia after 120 days. Membrane damage in the acrosome, bent mid piece, coiled tail, detached head and arrest of spermatogenesis beyond the level of spermatocytes were also observed [31].

Alcoholic extracts of Momordica charantia have been reported to exhibit antispermatogenic effects in dogs [10]. Oral administration of alcohol extracts of the seeds of Momordica charantia to male albino rats at a dose of $25 \mathrm{mg}$ per $100 \mathrm{~g} \mathrm{~b}$.w. for 35 days caused a decrease in the number of spermatocytes and spermatids, with the effects being more significant when administered through the intraperitoneal route [32]. The crude extract of garlic (Allium sativum) when administered to male rats at varying concentrations (5\%, $10 \%, 15 \%$ and $30 \%$ ) for 30 days caused an increase in the percentage of empty seminiferous tubules and brought about a decrease in serum testosterone levels, with the effects being invoked at a dose as low as $10 \%$ [33]. Furthermore, induction of germ-cell apoptosis through increased expression of caspase inhibitors such as Baculoviral IAP repeat-containing protein 3 (BIRC3) and Baculoviral IAP repeat-containing protein 2 (BIRC2) and activation of caspase-3 were also reported [34]. Pepper (Piper longum), a commonly used spice, is reported to induce sterility in laboratory male mice [35]. Piperine, an alkaloid extracted from the fruits and roots of black pepper, has been shown to cause damage to the germ cells and seminiferous tubules when administered orally for 30 days [36]. Suppression in the levels of antioxidant enzymes, and increase in lipid peroxidation in testis and epididymis along with activation of caspase 3 and Fas apoptotic proteins in testicular germ cells were reported when piperine was administered to male Wistar rats at doses of $10 \mathrm{mg}$ and $100 \mathrm{mg}$ for 30 days $[37,38]$.

Vincristin and vinblastin, two pharmacologically active compounds isolated from Catharanthus roseus or Vinca rosea, have since long been reported to interfere with reproduction $[39,40]$. A single injection of $15 \mu \mathrm{g}$ of vincristine and $40 \mu \mathrm{g}$ of vinblastin to adult rats was reported to cause degeneration of A4 spermatogonia, $48 \mathrm{~h}$ after injection. Changes in the seminiferous tubule and a decline in the percentage of primary spermatocytes, round and elongated spermatids were reported in rats when the extracts of Vinca rosea were administered at various doses [41]. Ocimum sanctum or Holy Bail or Tulsi has also been reported to hamper reproduction by targeting spermatogenesis, thereby leading to antifertility [42]. Accumulation of sperm in the lumen of seminiferous tubules was observed when rats were administered with ginger (Zingiber officinale) rhizome powder at doses of $50 \mathrm{mg}$ and $100 \mathrm{mg}$ for 20 consecutive days [43]. The rhizome extract of Curcuma longa at a dose of $600 \mathrm{mg}$ per $\mathrm{kg}$ b.w. for 56 and 84 days caused a reduction in the diameter of seminiferous tubules, loosening of the germinal epithelium, intraperitoneal vacuolation and mixing of spermatids at different stages of spermatogenesis in male Wistar rats, with the effects being reversible following cessation of treatment for 56 days [44].

The extracts from the roots of Tripterygium wilfordii, a Chinese herb that is used in the treatment of various diseases like rheumatoid arthritis, hepatitis, spondylitis and skin disorders, has been shown to exert powerful antifertility effects in rats and human males, with the effects being observed at doses much lower than the ones used to cure rheumatoid arthritis [45]. The glycosides of Tripterygium wilfordii at a daily dosage of $10 \mathrm{mg}$ for 7 weeks or 13 weeks and $20 \mathrm{mg}$ for 4 weeks or 10 weeks significantly inhibited spermatogenesis and the turnover of basic nuclear protein synthesis in the late elongated spermatids of rat testis [46]. Several other plants are also known to hamper fertility by targeting spermatogenesis at various stages. A list of few recently published articles on plants that impair spermatogenesis is summarized in Table 1.

\subsection{Plants that affect sperm motility and morphology}

The spermatozoa formed during the process of 
Table 1. Plants that affect spermatogenesis.

\begin{tabular}{|c|c|c|c|c|}
\hline Plant name & Plant part used/extract & Dose and duration & Observed effects & erences \\
\hline Allium sativum & Crude extract & $\begin{array}{l}5 \%, 10 \%, 15 \% \text { and } 30 \% \\
30 \text { days }\end{array}$ & $\begin{array}{l}\text { Dose-dependent decrease of increase in } \\
\text { the percentage empty seminiferous tubules. }\end{array}$ & {$[33]$} \\
\hline $\begin{array}{l}\text { Lagenaria breviflora } \\
\text { Robert }\end{array}$ & $\begin{array}{l}\text { Whole fruit } \\
\text { and ethanol }\end{array}$ & $\begin{array}{l}1000,2000,4000 \\
\text { and } 8000 \mathrm{mg} \mathrm{kg}^{-1} \text { day }^{-1} \\
14 \text { days }\end{array}$ & $\begin{array}{l}\text { Significant decrease in sperm motility and } \\
\text { viability. }\end{array}$ & {$[90]$} \\
\hline Azadirachta indica $A$. & Leaf and powder & $\begin{array}{l}0 \%, 5 \%, 10 \% \text { and } 15 \% \text { of } \\
\text { neem leaf meal; } 16 \text { weeks }\end{array}$ & $\begin{array}{l}\text { Mild depressive effect on spermatoge- } \\
\text { nesis, sperm quality and seminiferous } \\
\text { tubule diameter. }\end{array}$ & {$[101]$} \\
\hline Aegle marmelos & Leaf and ethanol extract & $\begin{array}{l}200 \text { and } 300 \mathrm{mg} \mathrm{kg} \mathrm{day}^{-1} \text {; } \\
60 \text { days }\end{array}$ & $\begin{array}{l}\text { Reduces sperm motility, concentration. } \\
\text { Morphological changes in the testis. } \\
\text { Reduced the surface area of Sertoli } \\
\text { and Leydig cells. }\end{array}$ & {$[72]$} \\
\hline Garcinia cambogia & $\begin{array}{l}\text { Seeds and } \\
\text { ethanol extract }\end{array}$ & $\begin{array}{l}100 \text { and } 200 \mathrm{mg} \mathrm{kg}^{-1} \text { day }^{-1} ; \\
6 \text { days per week for } 6 \text { weeks } \\
\text { treatment }\end{array}$ & $\begin{array}{l}\text { Distortion in the arrangement of the } \\
\text { spermatogenic cells. }\end{array}$ & [93] \\
\hline Dendrophthoe falcata & $\begin{array}{l}\text { Stem and } 70 \% \\
\text { methanol extract }\end{array}$ & $\begin{array}{l}100 \mathrm{mg} \mathrm{kg}^{-1} \text { day }^{-1} \\
60 \text { days }\end{array}$ & $\begin{array}{l}\text { Inhibition of spermatogenesis by dec- } \\
\text { reasing the weight of testis, epididymis } \\
\text { and accessory sex organs. } \\
\text { Reduced the Sertoli cell surface area. }\end{array}$ & [69] \\
\hline Juniperus phoenicea L. & $\begin{array}{l}\text { Cones and } \\
\text { ethanol extract }\end{array}$ & $\begin{array}{l}400 \text { or } 800 \mathrm{mg} \mathrm{kg}^{-1} \text { day }^{-1} \text {; } \\
21 \text { days }\end{array}$ & $\begin{array}{l}\text { Spermatogenic arrest and decreases } \\
\text { sperm motility, count. }\end{array}$ & [91] \\
\hline $\begin{array}{l}\text { Rosmarinus } \\
\text { officinalis } L \text {. }\end{array}$ & $\begin{array}{l}\text { Leaf and ethanol } \\
\text { extract }\end{array}$ & $\begin{array}{l}250 \text { and } 500 \mathrm{mg} \mathrm{kg}^{-1} \text { day }^{-1} \text {; } \\
63 \text { days }\end{array}$ & $\begin{array}{l}\text { Decreases spermatogenesis by decreasing } \\
\text { the primary and secondary spermatocyte } \\
\text { in the testis. }\end{array}$ & [102] \\
\hline Quassia amara & $\begin{array}{l}\text { Bark and } \\
\text { chloroform extract }\end{array}$ & $\begin{array}{l}12.5 \%, 25 \%, 50 \% \\
\text { and } 100 \% ; 15 \text { days }\end{array}$ & $\begin{array}{l}\text { Decreased sperm parameters, epididymal } \\
\alpha \text {-galactosidase activity and abnormal } \\
\text { sperms. }\end{array}$ & [92] \\
\hline Martynia аппиа & $\begin{array}{l}\text { Root and } \\
\text { ethanol extract }\end{array}$ & $\begin{array}{l}50,100 \text { and } \\
200 \mathrm{mg} \mathrm{kg}^{-1} \mathrm{day}^{-1}\end{array}$ & $\begin{array}{l}\text { Spermatogenic arrest by showing degeneration } \\
\text { of spermatocytes and a dose-related } \\
\text { reduction in sperm parameters. }\end{array}$ & {$[80]$} \\
\hline Mentha arvensis & $\begin{array}{l}\text { Leaf and petroleum } \\
\text { ether extract }\end{array}$ & $\begin{array}{l}10 \text { and } 20 \mathrm{mg} \text { per } \\
\text { animal per day; } 20 \text {, } \\
40 \text { and } 60 \text { days }\end{array}$ & $\begin{array}{l}\text { Reduced testis, epididymis weight and } \\
\text { spermiogram with normal morphology } \\
\text { of sperm. }\end{array}$ & {$[103]$} \\
\hline Hibiscus sabdariffa & $\begin{array}{l}\text { Calyx and aqueous } \\
\text { extract }\end{array}$ & $\begin{array}{l}1.15,2.30 \text { and } \\
4.60 \mathrm{~g} \mathrm{~kg}^{-1} \text { day }^{-1}\end{array}$ & Distortion of seminiferous tubules. & {$[104]$} \\
\hline Cestrum parqui & $\begin{array}{l}\text { Leaf and filtered } \\
\text { extract }\end{array}$ & $\begin{array}{l}40,62.5,100,150 \\
\text { and } 250 \mu \mathrm{g} \mathrm{mL}^{-1}\end{array}$ & $\begin{array}{l}\text { Spermicidal activity at high dose with } \\
\text { damage to sperm membrane. }\end{array}$ & {$[105]$} \\
\hline Tropaeolum tuberosum & $\begin{array}{l}\text { Tubers and aqueous } \\
\text { extract }\end{array}$ & $\begin{array}{l}1 \mathrm{~g} \mathrm{~kg}^{-1} \text { day }^{-1} \mathrm{~mL}^{-1} \\
7,12,21 \text { and } 42 \text { days }\end{array}$ & $\begin{array}{l}\text { Reduces testicular functions after one } \\
\text { spermatogenic cycle by reducing } \\
\text { spermatid and sperm number, daily } \\
\text { sperm production. }\end{array}$ & {$[106]$} \\
\hline Curcuma longa $L$. & $\begin{array}{l}\text { Rhizome and } \\
\text { aqueous extract }\end{array}$ & $\begin{array}{l}600 \mathrm{mg} \mathrm{kg}^{-1} \text { day }^{-1} \\
56 \text { and } 84 \text { days }\end{array}$ & Suppresses spermatogenesis & {$[44]$} \\
\hline Barleria prionitis & $\begin{array}{l}\text { Root and methanolic } \\
\text { extract }\end{array}$ & $\begin{array}{l}100 \mathrm{mg} \mathrm{kg}{ }^{-1} \text { day }^{-1} \text {; } \\
60 \text { days }\end{array}$ & $\begin{array}{l}\text { Spermatogenic cells such as primary } \\
\text { spermatocytes, secondary spermatocytes } \\
\text { and round spermatocytes were declined. }\end{array}$ & [107] \\
\hline
\end{tabular}


spermiogenesis are morphologically mature but immotile and gets released into the lumen of the seminerous tubule, which then proceeds into the rete testis via the seminiferous fluid. The peristaltic movements of the adjoining myoid cells of the testis transport the immotile spermatozoa through a series of tubules known as efferent ductules, which connects the retes testis to the head of the epididymis. The passage of the sperm through three segments of the epididymis-caput, corpus and cauda is very essential for the final maturation of the sperm [47]. The synthesis and secretion of various proteins by the epididymis, as well as the attainment of various morphological, biochemical and motile properties during the passage through the epididymis are fundamental for the fully fertilizing capabilities of spermatozoa. Reduced sperm number or altered sperm morphology may be indicative of the problems encountered during spermatogenesis or spermiogenesis or the impairment of epididymal environment. Several plant products are reported to alter the morphology of the sperm or to diminish its motility.

Testicular degeneration characterized by reduced number of cells in the epithelium along with reduction in the number of sperm cells was observed when the aqueous extract of Abrus precatorious was administered to male rats at doses of $400 \mathrm{mg}, 800 \mathrm{mg}$ and $1600 \mathrm{mg}$ per kg b.w. for 18 days [48]. The alcoholic seed extracts of Abrus precatorious at a dose of $100 \mathrm{mg}$ per $\mathrm{kg}$ b.w. for 60 days significantly lowered cauda epididymal sperm motility and brought about a decrease in the levels of succinate dehydrogenase and ATPase in the sperm of male albino rats. Scanning electron microscopic studies on sperm morphology revealed decapitation, acrosomal damage and formation of bulges on the midpiece region of sperms following exposure to Abrus precatorious seed extracts [49]. Irreversible impairment of the motility of human spermatozoa at a concentration of $20 \mathrm{mg}$ per $\mathrm{mL}$ of the methanol extract of Abrus precatorious seed extracts was reported, which may be due to the decline in cAMP and enhanced generation of reactive oxygen species [50]. A significant decrease in the density and motility of the ejaculated spermatozoa were observed in patients receiving the root extracts of Tripterygium wilfordii as treatment for rheumatoid arthritis [45]. Increased retained proximal cytoplasmic droplets in the sperm, separation of the heads and tails of the spermatozoa and reduced sperm motility were observed when mature rams were fed with locoweed, Astragalus lentiginosus [51]. Incubation of guinea spermatozoa with the crude aqueous extract of Echeveria gibbiflora caused a hypotonic-like effect, which included distention of the plasma membrane over the acrosomal region and formation of a huge head bubble [52]. Electron microscopic observation of human spermatozoa revealed the presence of a sticky dense material intercalated along the plasma membrane on exposure to a purified fraction from the crude aqueous extract of Echeveria gibbiflora [53].

Oral administration of ethanolic extracts of neem to adult male mice at $0.5 \mathrm{mg}, 1 \mathrm{mg}$ or $2 \mathrm{mg}$ per $\mathrm{kg}$ b.w. for 6 weeks interfered with sperm DNA and caused chromosome strand breakage, spindle disturbances and deregulation of genes responsible for sperm morphology. A linear decrease in the percentage of sperm motility was observed with various concentrations (1-50 mg per 1 million sperm) of neem leaf extract, with motility falling to absolute zero within $20 \mathrm{~s}$ of exposure to $3 \mathrm{mg}$ dose [54. An in vitro study on hamster sperm showed that piperine interferes with acrosome reaction through the inhibition of calcium influx by stimulation of efflux, thereby impairing fertility [55]. In our laboratory, we have demonstrated a reduction in rat sperm motility, viability and count on exposure to piperine at $10 \mathrm{mg}$ and $100 \mathrm{mg}$ per $\mathrm{kg}$ b.w. [38]. Graded doses of the mormodica seed extract induced abnormalities in the size and shape of rat sperm along with dorsoventral constrictions in the middle region of the sperm head, which was proposed to be due to alterations in cauda epididymal milieu and androgen deficiency [56]. An in vitro study on the effects of allitridum, an active principle from garlic, has been reported to inhibit sperm motility and complete immobilization of rat, hamster and human spermatozoa at a dose of $7.5 \mathrm{mg} \mathrm{mL}^{-1}$ of allitridum treatment [57]. In vitro studies on the crude aqueous extract of Allium sativum have been reported to reduce sperm viability, membrane disintegration of sperm and irreversible immobilization of ram epididymal and human ejaculated sperm at doses of $0.25 \mathrm{~g}$ and $0.5 \mathrm{~g}$ per $\mathrm{mL}$, respectively [58]. The benzene extract of Ocimum sanctum leaves when administered to male rats at a dose of $250 \mathrm{mg}$ per $\mathrm{kg}$ b.w. for 48 days was reported to decrease sperm count, motility and the forward velocity of the sperm. The effects were found to be reversible upon withdrawal of treatment for 2 weeks [59]. Although several studies have demonstrated the noxious effects of various plants and/or their products on sperm motility and morphology, the mechanism(s) involved in contributing these effects are poorly understood. Plants may induce 
deterioration of sperm functions either due to the direct action of the active ingredients of plants on sperm cells and/or by targeting Leydig cells or Sertoli cells and the associated functions. The later part of this review will discuss about the plants that are reported to target Sertoli cell/Leydig cell functions.

\subsection{Plants that affect Sertoli cells}

The somatic Sertoli cells have a very important role in controlling the process of spermatogenesis throughout the adult life. They foster the developing germ cells by regulating the flow of vital nutrients and growth factors through the tight junctions [60]. In addition, the rate and quality of spermatogenesis are determined by the number of Sertoli cells present [61]. Therefore, any agent that damages the viability and function of Sertoli cells may have profound effects on spermatogenesis. Chloroform extracts of the seeds of Carica papaya when administered to male albino rats and langur monkeys at a dose of $50 \mathrm{mg}$ per $\mathrm{kg} \mathrm{b}$.w. for 360 days caused reduction in nuclear and cytoplasmic volume and vacuolization of the Sertoli cells, with the effects being reversible 60-120 days after withdrawal of the treatment $[62,63]$. Intra-epithelial vacuoles of varying sizes in the cytoplasm of Sertoli cells and disturbances in the co-existence of Sertoli-Sertoli/ Sertoli-germ cell were observed when Azadirachta leaf powder was administered to albino rats for 48 days [64]. An in vitro study on the effects of mutiglycosides of Tripterygium wilfordii and gossypol acetate at a dose of 3.0 or $30 \mu \mathrm{g} \mathrm{mL}^{-1}$ on primary cultures of Leydig and Sertoli cells resulted in the complete death of both the cell types within $24 \mathrm{~h}$ of exposure. It was concluded that Sertoli cells are more sensitive than Leydig cells to both the compounds [65]. Enlargement of the Sertoli cells was observed when $400 \mathrm{mg}$ of the leaf extract of Thespesia populnea was administered to male Swiss mice for 15 days [66]. Pure theobromine when administered to male rats at a dose of $500 \mathrm{mg}$ for 7 days inhibited the binding ability of androgenbinding protein and reduced the androgen concentration in seminiferous tubule fluid, signifying Sertoli cells as primary targets for theobromine toxicity [67].

Root extracts of Barleria prionitis (100 mg per kg b.w.), methanolic extracts of Dendrophthoe falcata (100 mg per kg b.w.), methanolic extracts of Albizzia lebbeck bark (100 mg per kg b.w.), methanolic extracts of Tinospora cordifolia (100 mg per kg b.w.) and ethanolic extracts of Aegle marmelos leaves (300 mg per kg b.w.) are reported to reduce the cross-sectional surface area of Sertoli cells when administered orally to male Wistar rats for 60 days [68-72]. There are very few studies that elucidate the molecular mechanism of action by which plants impede the functions of Sertoli cells. Sertoli cells express androgen receptors and require intratesticular testosterone for their normal development and function. It is possible that plants impair Sertoli cell functions by targeting the intratesticular testosterone production by Leydig cells and/or at the level of the hypothalamo-pituitary axis.

\section{Plants that affect Leydig cells and steroidogenesis}

Apart from spermatogenesis, the testis performs another important function, the synthesis of androgens that are vital in maintaining spermatogenesis. The hormonal regulation of spermatogenesis is well organized, with a feed-back mechanism involving the hypothalamus, pituitary gland and testis [73]. The neurons of the hypothalamus synthesize and secrete gonadotropin-releasing hormone, which induces the production and release of LH and FSH from the pituitary gland. LH causes the synthesis of testosterone in the Leydig cells of the testis, which exerts a negative feedback on hormone release from the hypothalamus and pituitary [74]. FSH acts on Sertoli cells, resulting in the production of androgen-binding protein, which helps in the passage of testosterone through SertoliSertoli junctional complexes. Any factor that could perturb the LH-stimulated Leydig cell steroidogenesis could have an enormous impact on endocrine regulation of spermatogenesis and could lead to infertility. Numerous plant products are known to target Leydig cells and hinder their functions.

Several studies affirm the undisputable role of gossypol in impairing testicular spermatogeneis [75, 76]. Gossypol acetic acid, a polyphenolic compound isolated from the seeds of cotton plant when incubated with isolated rat interstitial cells at a dose of $50 \mu \mathrm{g} \mathrm{mL}$ caused a dramatic decrease in histochemical stain for $3-\beta-H S D$, proving the direct inhibitory effect of the compound [77]. Reduction in the levels of testosterone, LH and follicle-stimulating hormone was reported when the crude methanol extract of Quassia amara was administered to male albino rats [78]. Administration of the methanol extract of Sarcostemma acidum at a dose of $100 \mathrm{mg}$ to male albino rats for 60 days caused a decrease in the number of mature Leydig cells and an 
increase in the degeneration of Leydig cell population [79]. Ethanolic extracts of the roots of Martynia annua to male rats at doses of 100 and $200 \mathrm{mg}$ per $\mathrm{kg}$ b.w. for 60 days caused Leydig cell atrophy and a significant reduction in the serum concentration of LH and testosterone [80]. Leydig cell nuclear area and mature Leydig cell numbers were significantly reduced on oral administration of $70 \%$ methanolic extract of Tinospora cordifolia stem to male rats at the dose level of $100 \mathrm{mg}$ per rat per day for 60 days [71]. Mentha piperita labiatae $\left(20 \mathrm{~g} \mathrm{~L}^{-1}\right)$ and Mentha spicata labiatae $\left(20 \mathrm{~g} \mathrm{~L}^{-1}\right)$ herbal teas when fed to Wistar rats increased the FSH and $\mathrm{LH}$ levels and decreased total testosterone levels [81]. Suppression of the activities of steroidogenic enzymes including the P450 side-chain cleavage enzyme, $3 \beta$-hydroxysteroid dehydrogenase, $17 \alpha$-hydroxylase, $20 \alpha$-hydroxylase and $17 \beta$-hydroxysteroid dehydrogenase, was observed when primary mouse Leydig cells were incubated with varying concentrations of crude Toona sinensis [82]. The leaves of Azadirachta indica when administered orally at a dose of $500 \mathrm{mg}$ per $\mathrm{kg}$ b.w. exhibited a regression and decrease in the number of Leydig cells and their nuclear diameter, indicating androgen deficiency [83]. Carica papaya seed extracts when administered orally at doses of 50 and $100 \mathrm{mg}$ per $\mathrm{kg}$ b.w. for 8 weeks to sexually mature Wistar rats caused pronounced hypertrophy of pituitary gonadotrophs and degeneration of Leydig cells [84]. Palmitine hydrochloride isolated from the roots of Berberis chitria at a dose of $30 \mathrm{mg}$ per $\mathrm{kg}$ per day when administered orally to dogs for 30 days resulted in $66 \%$ and $27 \%$ reduction, respectively, in mature and immature Leydig cells [85].

A significant reduction in the levels of serum testosterone and $\mathrm{LH}$ was reported when crude extracts of garlic were administered to male rats for 30 days [33]. Dose-dependent decrease in the enzyme activity of $3 \alpha, 3 \beta, 17 \beta$-hydroxysteroid dehydrogenases and degeneration of Leydig cells were reported when Abrus precatorius was administered to male rats [86]. Ethanolic extracts of Colebrookea oppositifolia (200 mg) when administered orally for 8-10 weeks was reported to cause a decrease in the nuclear and cytoplasmic surface area of Leydig cells [87]. Atrophy of the Leydig cells was observed when the leaf extracts of Azadirachta indica and flower extract of Malvaviscus conzattii were administered to male albino rats [83, 88]. Table 2 summarizes a few recent articles on plants that are reported to impair Leydig cell functions. Most of the plants impair steroidogenesis by targeting the enzymes involved in the process at the level of Leydig cells and/or at the level of the hypothalamo-pituitarygonadal loop. Additional studies are warranted to understand intensely the molecular mechanisms by which plants or their active ingredients hamper steroidogenesis in various species.

\section{Conclusion}

The toxic effects of most of the plants on reproduction were identified while administering them for therapeutic use and/or during contraceptive research. Although a few plants have reached clinical trials, most of them failed the trails due to their toxicity or due to the irreversibility of the effects. Several plants that are reported to have beneficial effects against various ailments were later found to have harmful effects on reproduction. Future research should be directed towards studying the toxic effects of all the commonly used plants. The detailed mechanism of action of natural products in inducing reproductive toxicity should be elucidated.

\section{Acknowledgment}

Dr PP Mathur acknowledges the receipt of financial support from the Department of Science and Technology, Govt. of India under the projects (1) SP/SO/B-65/99, (2) DST-FIST and (3) the Indian Council of Medical Research. Shereen Cynthia D'Cruz acknowledges the Indian Council of Medical Research, New Delhi, India for the Senior Research Fellowship. The authors also thank the staff of Bioinformatics Centre, Pondicherry University, Pondicherry, India for providing various facilities.

\section{References}

1 Hess RA, Renato de Franca L. Spermatogenesis and cycle of the seminiferous epithelium. Adv Exp Med Biol 2008; 636: $1-15$.

2 Ge R, Chen G, Hardy MP. The role of the Leydig cell in spermatogenic function. Adv Exp Med Biol 2008; 636: 255-69.

3 Litscher ES, Williams Z, Wassarman PM. Zona pellucida glycoprotein ZP3 and fertilization in mammals. Mol Reprod Dev 2009; 76: 933-41.

4 Saradha B, Mathur PP. Effect of environmental contaminants on male reproduction. Environ Toxicol Pharmacol 2006; 21: 34-41.

5 Kritiker KR, Basu BD. Indian Medicinal Plants. New Canaught Place, Dehradun, India: Bishen Singh, Mahendra 
Table 2. Plants that affects steroidogenesis.

\begin{tabular}{|c|c|c|c|c|}
\hline Plant name & Plant part used/extract & Dose and duration & Observed effects & erences \\
\hline Allium sativum & Crude extract & $\begin{array}{l}5 \%, 10 \%, 15 \% \text { and } 30 \% ; \\
30 \text { days }\end{array}$ & Reduces testosterone secretion & {$[33]$} \\
\hline Aegle marmelos & Leaf and ethanol extract & $\begin{array}{l}200 \text { and } 300 \mathrm{mg} \mathrm{kg}^{-1} \text { day }^{-1} \text {; } \\
60 \text { days }\end{array}$ & Reduces testosterone levels & {$[72]$} \\
\hline Aegle marmelos & Leaf and aqueous extract & $\begin{array}{l}50 \text { mg per } 100 \text { g b.w. per day; } \\
28 \text { days }\end{array}$ & $\begin{array}{l}\text { Steroidogenesis was reduced with } \\
\text { a reduction in germ cells in testis }\end{array}$ & [89] \\
\hline Capparis aphylla & $\begin{array}{l}\text { Whole plant and ethanol } \\
\text { extract }\end{array}$ & $\begin{array}{l}50,100 \text { and } 200 \mathrm{mg} \mathrm{kg}^{-1} \text { day }^{-1} \text {; } \\
18 \text { days }\end{array}$ & Reduces steroidogenic enzymes & [96] \\
\hline Garcinia cambogia & Seeds and ethanol extract & $\begin{array}{l}100 \text { and } 200 \mathrm{mg} \mathrm{kg}^{-1} \mathrm{day}^{-1} ; 6 \text { days } \\
\text { a week for } 6 \text { weeks treatment }\end{array}$ & Degeneration of the Leydig cells & [93] \\
\hline Dendrophthoe falcate & Stem methanol extract & $\begin{array}{l}50,100 \text { and } 200 \mathrm{mg} \mathrm{kg}^{-1} \text { day }^{-1} \text {; } \\
60 \text { days }\end{array}$ & $\begin{array}{l}\text { Decreases serum testosterone } \\
\text { levels }\end{array}$ & [94] \\
\hline Juniperus phoenicea L. & Cones and ethanol extract & $\begin{array}{l}400 \text { or } 800 \mathrm{mg} \mathrm{kg}^{-1} \mathrm{day}^{-1} \\
21 \text { days }\end{array}$ & Decreases testosterone levels & [91] \\
\hline Martynia аппиа & Root and ethanol extract & $\begin{array}{l}50,100 \text { and } 200 \mathrm{mg} \mathrm{kg}^{-1} \mathrm{day}^{-1} \text {; } \\
60 \text { days }\end{array}$ & Degeneration of Leydig cells & {$[80]$} \\
\hline Syzygium aromaticum $L$. & Flower buds and hexane & $\begin{array}{l}15,30 \text { and } 60 \mathrm{mg} \mathrm{kg}^{-1} \mathrm{day}^{-1} \text {; } \\
35 \text { days }\end{array}$ & $\begin{array}{l}\text { Reduction in the steroidogenic } \\
\text { enzymes and testosterone } \\
\text { levels at higher dose }\end{array}$ & [97] \\
\hline Bulbine natalensis & Stem and aqueous extract & $\begin{array}{l}25,50 \text { and } 100 \mathrm{mg} \mathrm{kg}^{-1} \mathrm{day}^{-1} \text {; } \\
7 \text { days }\end{array}$ & $\begin{array}{l}\text { Decreases testosterone and } \\
\text { progesterone at high dose }\end{array}$ & [98] \\
\hline Abelmoschus esculentus & $s$ Fruit and methanolic extract & $70 \mathrm{mg} \mathrm{kg}^{-1}$ day $^{-1} ; 28$ days & Decreases serum testosterone levels & [99] \\
\hline Albizia. lebbeck L & Bark and methanolic extract & $100 \mathrm{mg} \mathrm{kg}^{-1}$ day $^{-1} ; 60$ days & $\begin{array}{l}\text { Decrease in Leydig cells nuclear } \\
\text { area and number of mature Leydig cell } \\
\text { Decreases serum testosterone levels }\end{array}$ & $\operatorname{ls}^{[70]}$ \\
\hline $\begin{array}{l}\text { Curcuma longa } L . \\
\text { Psoralea corylifolia }\end{array}$ & $\begin{array}{l}\text { Crude alcoholic extract } \\
\text { Crude extract }\end{array}$ & $\begin{array}{l}500 \mathrm{mg} \mathrm{kg}^{-1} \text { day }^{-1} ; 60 \text { days } \\
10 \mathrm{~g} \mathrm{~kg}^{-1} \text { - single dose; } \\
3,7 \text { days after treatment }\end{array}$ & Decreases serum testosterone levels & {$[100]$} \\
\hline Chromolaena odoratum $L$. & Leaves and aqueous extract & $\begin{array}{l}250 \text { and } 500 \mathrm{mg} \mathrm{kg}^{-1} \text { day }^{-1} \text {; } \\
14 \text { days }\end{array}$ & Decreases serum testosterone levels & {$[108]$} \\
\hline
\end{tabular}

Pal Singh; 1975. p785-8.

6 Patwardhan BWD, Pushpangadan P, Bhatt N. Ayurveda and Traditional Chinese Medicine: A comparative overview. Evid Based Compl Alt 2005; 2 .

7 WHO. Traditional Medicine Strategy 2002-2005. Geneva: WHO; 2002.

8 McDonald A. A Botanical Perspective on the Identity of Soma (Nelumbo nucifera Gaertn.) Based on Scriptural and Iconographic Records. New York: Botanical Garden Press; Supplement (Winter, 2004). pp. S147-50+S51+S52-73.

9 Saez JM, Avallet O, Lejeune H, Chatelain PG. Cell-cell communication in the testis. Horm Res 1991; 36: 104-15.

10 Dixit VP, Khanna P, Bhargava SK. Effects of Momordica charantia $L$. fruit extract on the testicular function of $\mathrm{dog}$. Planta Med 1978; 34: 280-6.

11 Udoh P, Kehinde A. Studies on antifertility effect of pawpaw seeds (Carica papaya) on the gonads of male albino rats. Phytother Res 1999; 13: 226-8.

12 Liu GZ, Lyle KC, Cao J. Clinical trial of gossypol as a male contraceptive drug. Part I. Efficacy study. Fertil Steril 1987; 48: 459-61.

13 Dixit VP, Gupta CL, Agrawal M. Testicular degeneration and necrosis induced by chronic administration of Cannabis extract in dogs. Endokrinologie 1977; 69: 299-305.

14 Mandal TK, Das NS. Testicular toxicity in Cannabis extract treated mice: association with oxidative stress and role of antioxidant enzyme systems. Toxicol Ind Health 2010; 26: $11-23$.

15 Nahas GG, Frick HC, Lattimer JK, Latour C, Harvey D. Pharmacokinetics of THC in brain and testis, male gametotoxicity and premature apoptosis of spermatozoa. Hum Psychopharmacol 2002; 17: 103-13.

16 Joshi AR, Ahamed RN, Pathan KM, Manivannan B. Effect of Azadirachta indica leaves on testis and its recovery in 
albino rats. Indian J Exp Biol 1996; 34: 1091-4.

17 Choudhary DN, Singh JN, Verma SK, Singh BP. Antifertility effects of leaf extracts of some plants in male rats. Indian J Exp Biol 1990; 28: 714-6.

18 Mishra RK, Singh SK. Effect of aqueous leaf extract of Azadirachta indica on the reproductive organs in male mice. Indian J Exp Biol 2005; 43: 1093-103.

19 Srivastava MK, Raizada RB. Lack of toxic effect of technical azadirachtin during postnatal development of rats. Food Chem Toxicol 2007; 45: 465-71.

20 Dhongade RK, Kavade SG, Damle RS. Neem oil poisoning. Indian Pediatr 2008; 45: 56-7.

21 Sutton NM, Bates N, Campbell A. Apparent adverse reactions to neem (margosa) oil in cats. Vet Rec 2009; 164: 592-3.

22 Lai SM, Lim KW, Cheng HK. Margosa oil poisoning as a cause of toxic encephalopathy. Singapore Med J 1990; 31: 463-5.

23 Balakrishnan V, Pillai NR, Santhakumari G. Ventricular fibrillation and cardiac arrest due to neem leaf poisoning. J Assoc Physicians India 1986; 34: 536.

24 Coutinho EM. Gossypol: a contraceptive for men. Contraception 2002; 65: 259-63.

25 Wang YE, Luo YD, Tang XC. Studies on the anti-fertility actions of cotton seed meal and gossypol (author's transl). Yao Xue Xue Bao 1979; 14: 663-9.

26 Reidenberg MM, Gu ZP, Lorenzo B, Coutinho E, Athayde $\mathrm{C}$, et al. Differences in serum potassium concentrations in normal men in different geographic locations. Clin Chem 1993; 39: 72-5.

27 Waites GM, Wang C, Griffin PD. Gossypol: reasons for its failure to be accepted as a safe, reversible male antifertility drug. Int J Androl 1998; 21: 8-12.

28 Bodhankar SL, Garg SK, Mathur VS. Antifertility screening of plants. Part IX. Effect of five indigenous plants on early pregnancy in female albino rats. Indian J Med Res 1974; 62: 831-7.

29 Chinoy NJ, Ranga Geetha M. Effects of Carica papaya seed extracts on the physiology of the vas deferens of albino rats. Acta Eur Fertil 1984; 15: 59-65.

30 Lohiya NK, Goyal RB. Antifertility investigations on the crude chloroform extract of Carica papaya Linn. seeds in male albino rats. Indian J Exp Biol 1992; 30: 1051-5.

31 Lohiya NK, Mishra PK, Pathak N, Manivannan B, Jain SC. Reversible azoospermia by oral administration of the benzene chromatographic fraction of the chloroform extract of the seeds of Carica papaya in rabbits. Adv Contracept 1999; 15: 141-61.

32 Naseem MZ, Patil SR, Ravindra, Patil RS. Antispermatogenic and androgenic activities of Momordica charantia (Karela) in albino rats. J Ethnopharmacol 1998; 61: 9-16.

33 Hammami I, Nahdi A, Mauduit C, Benahmed M, Amri $\mathrm{M}$, et al. The inhibitory effects on adult male reproductive functions of crude garlic (Allium sativum) feeding. Asian J Androl 2008; 10: 593-601.

34 Hammami I, Amara S, Benahmed M, El May MV, Mauduit C. Chronic crude garlic-feeding modified adult male rat testicular markers: mechanisms of action. Reprod Biol
Endocrinol 2009; 7: 65.

35 Munshi SR, Rao SS. Antifertility activity of an indigenous plant preparation (ROC-101). I. Effect on reproduction. Indian J Med Res 1972; 60: 1054-60.

36 Malini T, Manimaran RR, Arunakaran J, Aruldhas MM, Govindarajulu P. Effects of piperine on testis of albino rats. J Ethnopharmacol 1999; 64: 219-25.

37 D'Cruz SC, Vaithinathan S, Saradha B, Mathur PP. Piperine activates testicular apoptosis in adult rats. J Biochem Mol Toxicol 2008; 22: 382-8.

38 D'Cruz SC, Mathur PP. Effect of piperine on the epididymis of adult male rats. Asian J Androl 2005; 7: 363-8.

39 Joshi MS, Ambaye RY. Effect of alkaloids from Vinca rosea L. on spermatogenesis in male rats. Indian J Exp Biol 1968; 6: $256-7$.

40 Murugavel T, Akbarsha MA. Anti-spermatogenic effect of Vinca rosea Linn. Indian J Exp Biol 1991; 29: 810-2.

41 Bustos-Obregon E, Lopez ML. Selective effect of Vinca rosea $L$. alkaloids on type A4 rat spermatogonium. Andrologie 1973; 5: 245-7.

42 Kasinathan S, Ramakrishnan S, Basu SL. Antifertility effect of Ocimum sanctum L. Indian J Exp Biol 1972; 10: 23-5.

43 Khaki A, Fathiazad F, Nouri M, Khaki AA, Ozanci CC, et al. The effects of ginger on spermatogenesis and sperm parameters of rat. Iranian J Reprod Med 2009; 7: 7-12.

44 Mishra RK, Singh SK. Reversible antifertility effect of aqueous rhizome extract of Curcuma longa L. in male laboratory mice. Contraception 2009; 79: 479-87.

45 Zhen QS, Ye X, Wei ZJ. Recent progress in research on Tripterygium: a male antifertility plant. Contraception 1995 ; 51: 121-9.

46 Lu QX. Effect of glycosides of Tripterygium wilfordii Hook on the reproductive system and major organs of male rats. Zhongguo Yi Xue Ke Xue Yuan Xue Bao 1990; 12: 203-7.

47 Bedford JM. Evolution of the sperm maturation and sperm storage functions of the epididymis. Baltimore: Urban and Schwarzenberg; 1979. pp. 7-21.

48 Adedapo AA, Omoloye OA, Ohore OG. Studies on the toxicity of an aqueous extract of the leaves of Abrus precatorius in rats. Onderstepoort J Vet Res 2007; 74: 31-6.

49 Rao MV. Antifertility effects of alcoholic seed extract of Abrus precatorius Linn. in male albino rats. Acta Eur Fertil 1987; 18: 217-20.

50 Ratnasooriya WD, Amarasekera AS, Perera NS, Premakumara GA. Sperm antimotility properties of a seed extract of Abrus precatorius. J Ethnopharmacol 1991; 33: 85-90.

51 Panter KE, James LF, Hartley WJ. Transient testicular degeneration in rams fed locoweed (Astragalus lentiginosus). Vet Hum Toxicol 1989; 31: 42-6.

52 Delgado NM, Taboada Ramirez J, Ortega Hernandez A, Merchant-Larios H, Sanchez-Vazquez ML, et al. Effects of a purified fraction from Echeveria gibbiflora aqueous crude extract on guinea-pig spermatozoa. Phytother Res 1999; 13: 46-9.

53 Reyes R, Merchant-Larios H, Ortega-Hernandez A, Delgado NM. Male contraception, IV: hypotonic-like effect from Echeveria gibbiflora on human sperm. Arch Androl 2002; 48: 443-9.

54 Awasthy KS. Genotoxicity of a crude leaf extract of neem in 
male germ cells of mice. Cytobios 2001; 106 (Suppl 2): 151-64.

55 Piyachaturawat P, Sriwattana W, Damrongphol P, Pholpramool C. Effects of piperine on hamster sperm capacitation and fertilization in vitro. Int J Androl 1991; 14: 283-90.

56 Girini MM, Ahamed RN, Aladakatti RH. Effect of graded doses of Momordica charantia seed extract on rat sperm: scanning electron microscope study. J Basic Clin Physiol Pharmacol 2005; 16: 53-66.

57 Qian YX, Shen PJ, Xu RY, Liu GM, Yang HQ, et al. Spermicidal effect in vitro by the active principle of garlic. Contraception 1986; 34: 295-302.

58 Chakrabarti K, Pal S, Bhattacharyya AK. Sperm immobilization activity of Allium sativum L. and other plant extracts. Asian J Androl 2003; 5: 131-5.

59 Ahmed M, Ahamed RN, Aladakatti RH, Ghosesawar MG. Reversible anti-fertility effect of benzene extract of Ocimum sanctum leaves on sperm parameters and fructose content in rats. J Basic Clin Physiol Pharmacol 2002; 13: 51-9.

60 Griswold MD. The central role of Sertoli cells in spermatogenesis. Semin Cell Dev Biol 1998; 9: 411-6.

61 Petersen C, Soder O. The sertoli cell-a hormonal target and 'super' nurse for germ cells that determines testicular size. Horm Res 2006; 66: 153-61.

62 Manivannan B, Mittal R, Goyal S, Ansari AS, Lohiya NK. Sperm characteristics and ultrastructure of testes of rats after long-term treatment with the methanol subfraction of Carica papaya seeds. Asian J Androl 2009; 11: 583-99.

63 Lohiya NK, Manivannan B, Goyal S, Ansari AS. Sperm motility inhibitory effect of the benzene chromatographic fraction of the chloroform extract of the seeds of Carica papaya in langur monkey, Presbytis entellus entellus. Asian J Androl 2008; 10: 298-306.

64 Aladakatti RH, Ahamed RN. Changes in Sertoli cells of albino rats induced by Azadirachta indica A. Juss leaves. J Basic Clin Physiol Pharmacol 2005; 16: 67-80.

65 Lan ZJ, Gu ZP, Lu RF, Zhuang LZ. Effects of multiglycosides of Tripterygium wilfordii (GTW) on rat fertility and Leydig and Sertoli cells. Contraception 1992; 45: 249-61.

66 Krishnamoorthy P, Vaithinathan S. Effect of the extract of Thespesia populnea leaves on mice testis. J Environ Biol 2003; 24: 327-30.

67 Wang Y, Waller DP. Theobromine toxicity on Sertoli cells and comparison with cocoa extract in male rats. Toxicol Lett 1994; 70: 155-64.

68 Gupta RS, Kumar P, Dixit VP, Dobhal MP. Antifertility studies of the root extract of the Barleria prionitis Linn in male albino rats with special reference to testicular cell population dynamics. J Ethnopharmacol 2000; 70: 111-7.

69 Gupta RS, Kachhawa JB, Sharma A. Effect of methanolic extract of Dendrophthoe falcata stem on reproductive function of male albino rats. J Herbal Pharmacother 2007; 7 : $1-13$.

70 Gupta RS, Kachhawa JB, Chaudhary R. Antispermatogenic, antiandrogenic activities of Albizia lebbeck (L.) Benth bark extract in male albino rats. Phytomedicine 2006; 13: 277-83.

71 Gupta RS, Sharma A. Antifertility effect of Tinospora cordifolia (Willd.) stem extract in male rats. Indian J Exp Biol 2003; 41: 885-9.
72 Chauhan A, Agarwal M. Reversible changes in the antifertility induced by Aegle marmelos in male albino rats. Syst Biol Reprod Med 2008; 54: 240-6.

73 Sofikitis N, Giotitsas N, Tsounapi P, Baltogiannis D, Giannakis D, Pardalidis N. Hormonal regulation of spermatogenesis and spermiogenesis. J Steroid Biochem Mol Biol 2008; 109: 323-30.

74 Dufau ML, Winters CA, Hattori M, Aquilano D, Baranao $\mathrm{JL}$, et al. Hormonal regulation of androgen production by the Leydig cell. J Steroid Biochem 1984; 20: 161-73.

75 Udoh P, Patil DR, Deshpande MK. Histopathological and biochemical effects of gossypol acetate on pituitary-gonadal axis of male albino rats. Contraception 1992; 45: 493-509.

76 Zhuang LZ, Gu ZP, Chang CC. Comparison of sensitivities of rat spermatozoa, Sertoli and Leydig cells to gossypol acetic acid in vitro by the LD50. Zhongguo Yao Li Xue Bao 1986; 7: 563-7.

77 Paz GF, Homonnai ZT. Effect of the antifertility agent, gossypol acetic acid, on the metabolism and testosterone secretion of isolated rat interstitial cells in vitro. Contraception 1984; 29: 543-52.

78 Raji Y, Bolarinwa AF. Antifertility activity of Quassia amara in male rats-in vivo study. Life Sci 1997; 61: 1067-74.

79 Venma PK, Sharma A, Mathur A, Sharma P, Gupta RS, et al. Effect of Sarcostemma acidum stem extract on spermatogenesis in male albino rats. Asian J Androl 2002; 4: 43-7.

80 Mali PC, Ansari AS, Chaturvedi M. Antifertility effect of chronically administered Martynia annua root extract on male rats. J Ethnopharmacol 2002; 82: 61-7.

81 Akdogan M, Ozguner M, Kocak A, Oncu M, Cicek E. Effects of peppermint teas on plasma testosterone, folliclestimulating hormone, and luteinizing hormone levels and testicular tissue in rats. Urology 2004; 64: 394-8.

82 Poon SL, Leu SF, Hsu HK, Liu MY, Huang BM. Regulatory mechanism of Toona sinensis on mouse Leydig cell steroidogenesis. Life Sci 2005; 76: 1473-87.

83 Aladakatti RH, Ahamed RN. Ultrastructural changes in Leydig cells and cauda epididymal spermatozoa induced by Azadirachta indica leaves in albino rats. Phytother Res 2005; 19: 756-66.

84 Udoh P, Essien I, Udoh F. Effects of Carica papaya (paw paw) seeds extract on the morphology of pituitary-gonadal axis of male Wistar rats. Phytother Res 2005; 19: 1065-8.

85 Gupta RS, Dixit VP. Testicular cell population dynamics following palmitine hydroxide treatment in male dogs. J Ethnopharmacol 1989; 25: 151-7.

86 Sinha S, Mathur RS. Effect of steroidal fraction of seeds of Abrus precatorius Linn. on rat testis. Indian J Exp Biol 1990; 28: 752-6.

87 Gupta RS, Yadav RK, Dixit VP, Dobhal MP. Antifertility studies of Colebrookia oppositifolia leaf extract in male rats with special reference to testicular cell population dynamics. Fitoterapia 2001; 72: 236-45.

88 Chakraborty S, Pakrashi A. Antifertility effect of chronically administered Malviscus conzattii flower extract on fertility of male rats. Contraception 1991; 43: 273-85.

89 Das UK, Maiti R, Jana D, Ghosh D. Effect of aqueous 
extract of leaf of Aegle marmelos on testicular activities in rats. Iran J Pharmacol Ther 2006; 5: 21-5.

90 Saba AB, Oridupa OA, Oyeyemi MO, Osanyigbe OD. Spermatozoa morphology and characteristics of male wistar rats administered with ethanolic extract of Lagenaria breviflora roberts. Afr J Biotechnol 2009; 8: 1170-5.

91 Shkukani H, Salhab A, Disi A, Shomaf M, Al Quadan F. Antifertility effect of ethanolic extract of Juniperus phoenica (L.) in male albino rats. J Herbal Pharmacother 2007; 7: 179-89.

92 Parveen S, Das S, Kundra CP, Pereira BM. A comprehensive evaluation of the reproductive toxicity of Quassia amara in male rats. Reprod Toxicol 2003; 17: 45-50.

93 Oluyemi KA, Jimoh OR, Adesanya OA, Omotuyi IO, Josiah SJ, et al. Effects of crude ethanolic extract of Garcinia cambogia on the reproductive system of male wistar rats (Rattus novergicus). Afr J Biotechnol 2007; 6: 1236-8.

94 Gupta RS, Kachhawa JB. Evaluation of contraceptive activity of methanol extract of Dendrophthoe falcata stem in male albino rats. J Ethnopharmacol 2007; 112: 215-8.

95 Ashok P, Meenakshi B. Contraceptive effect of Curcuma longa $(L$. $)$ in male albino rat. Asian J Androl 2004; 6: 71-4.

96 Sarathchandran I, Manavalan R, Akbarsha MA, Kadalmani B, Karar PK. Effect of ethanolic extract of Capparis aphylla (Roth) on testicular steroidogenesis in rat. J Biol Sci 2007; 7: 582-4.

97 Mishra RK, Singh SK. Safety assessment of Syzygium aromaticum flower bud (clove) extract with respect to testicular function in mice. Food Chem Toxicol 2008; 46: 3333-8.

98 Yakubu MT, Afolayan AJ. Reproductive toxicologic evaluations of Bulbine natalensis Baker stem extract in albino rats. Theriogenology 2009; 72: 322-32.

99 Olatunji-Bello II, Ijiwole2 T, Awobajo FO. Evaluation of the deleterious effects of aqueous fruit extract of Abelmoschus esculentus (Okro fruit) ond some male reproductive parameters in sprague dawley rats. J Phytol
2009; 1: 461-8.

100 Takizawa T, Mitsumori K, Takagi H, Nasu M, Yasuhara K, et al. Sequential analysis of testicular lesions and serum hormone levels in rats treated with a Psoralea corylifolia extract. Food Chem Toxicol 2004; 42: 1-7.

101 Ogbuewu IP, Okoli IC, Iloeje MU. Semen quality characteristics, reaction time, testis weight and seminiferous tubule diameter of buck rabbits fed neem (Azadirachta indica A. Juss) leaf meal based diets. Iran J Reprod Med 2009; 7: 23-8.

102 Nusier MK, Bataineh HN, Daradkah HM. Adverse effects of rosemary (Rosmarinus officinalis L.) on reproductive function in adult male rats. Exp Biol Med (Maywood) 2007; 232: 809-13.

103 Sharma N, Jocob D. Antifertility investigation and toxicological screening of the petroleum ether extract of the leaves of Mentha arvensis L. in male albino mice. J Ethnopharmacol 2001; 75: 5-12.

104 Orisakwe OE, Husaini DC, Afonne OJ. Testicular effects of sub-chronic administration of Hibiscus sabdariffa calyx aqueous extract in rats. Reprod Toxicol 2004; 18: 295-8.

105 Souad K, Ali S, Mounir A, Mounir TM. Spermicidal activity of extract from Cestrum parqui. Contraception 2007; 75: 152-6.

106 Cardenas-Valencia I, Nieto J, Gasco M, Gonzales C, Rubio $\mathrm{J}$, et al. Tropaeolum tuberosum (Mashua) reduces testicular function: effect of different treatment times. Andrologia 2008; 40: 352-7.

107 Verma PK, Sharma A, Joshi SC, Gupta RS, Dixit VP. Effect of isolated fractions of Barleria prionitis root methanolic extract on reproductive function of male rats: preliminary study. Fitoterapia 2005; 76: 428-32.

108 Yakubu MT, Akanji MA, Oladiji AT. Evaluation of antiandrogenic potentials of aqueous extract of Chromolaena odoratum (L.) K. R. leaves in male rats. Andrologia 2007; 39: $235-43$. 